\title{
Rancang Bangun Sistem Informasi Marketplace Penyewaan Lapangan Futsal Berbasis Web
}

\author{
Putu Sidiarta ${ }^{1)}$, Anak Agung Ayu Putri Ardyanti ${ }^{2)}$, I Gede Juliana Eka Putra ${ }^{3)}$ \\ 1),2),3) Prodi Teknik Informatika STMIK Primakara Denpasar Bali \\ Email : putusidiarta@gmail.com ${ }^{1)}$, putri.ardyanti@primakara.ac.id ${ }^{2)}$, gedejep@primakara.ac.id ${ }^{3)}$
}

\begin{abstract}
Abstrak - Aplikasi marketplace penyewaan lapangan futsal ini digunakan untuk memudahkan penyewa lapangan futsal dalam menentukan penyewaan lapangan futsal dengan memberikan informasi secara detail pada setiap penyedia lapangan futsal yang ada serta untuk membantu penyewa lapangan futsal dalam mendapatkan informasi ketersediaan jadwal lapangan kosong secara real time, sehingga memberikan kemudahan dalam melakukan proses penyewaan jadwal lapangan futsal tanpa harus datang langsung ke tempat futsal. Pembuatan aplikasi ini dilakukan dengan Metode Waterfall. Aplikasi ini di implementasikan dengan Framework Codeigniter, dan dibuat dengan bahasa pemograman PHP, serta MySQL sebagai databasennya, dan untuk metode pengujian sistem menggunakan black box testing. Aplikasi ini dapat digunakan oleh 3 pengguna, yaitu admin, penyedia dan penyewa. Admin dapat mengelola penyedia dan penyewa. Penyedia dapat mengelola detail informasi yang disediakan, data lapangan, harga sewa, info turnamen, info nonton bareng, info kualitas lapangan dan info fasilitas lapangan. Penyewa dapat memilih jadwal lapangan yang ingin dipesan, melakukan pemesanan lapangan, konfirmasi pembayaran, dan cari lawan sparring.
\end{abstract}

Kata Kunci: Penyewaan, Marketplace, Futsal, Website, PHP, CodeIgniter, MySQL

Abstract-The market application of these futsal fields is to provide futsal tenants in determining field rentals by providing detailed information on each existing futsal field provider and also to help tenants of futsal field in getting real time information in real time, providing facilities in doing scheduling process futsal field without having to come directly to place futsal. Making this application is done by Waterfall method. This application is implemented with Codeigniter framework, and made with PHP programming language, and MySQL as database, and for system testing method using black box testing. This application can be done by 3 users, namely admin, provider and tenant. Admins can manage providers and tenants. Providers can manage detailed information provided, field data, rental rates, tournament info, info together, field quality info and field facility info. Tenants can choose the exam schedule to be ordered, place a field order, confirm payment, and look for sparring opponents.

Index Terms: Leasing, Marketplace, Futsal, Website, PHP, CodeIgniter, MySQL. 


\section{Pendahuluan}

\subsection{Latar Belakang}

Informasi jadwal lapangan yang kosong pada setiap lapangan futsal yang ada sangat dibutuhkan oleh banyak penyewa lapangan futsal saat ingin melakukan penyewaan lapangan futsal dan untuk menentukan jadwal lapangan yang ingin dipesan, namun untuk mengetahui jadwal lapangan yang kosong penyewa lapangan futsal harus menanyakan ketersediaan jadwal kepada penyedia lapangan futsal dengan cara datang langsung ke lokasi tempat futsal yang lapangannya ingin dipesan atau dengan cara menghubungi penyedia lapangan futsal melalui telepon. Dengan demikian informasi jadwal lapangan kosong yang didapatkan oleh penyewa lapangan futsal tidak didapatkan secara real time, penyewa lapangan futsal tidak mendapatkan informasi secara lengkap mengenai jadwal-jadwal yang kosong dari penyedia lapangan futsal sebelum bertanya secara detail melalui telepon atau melihat secara langsung dengan cara datang langsung ke lokasi penyedia lapangan futsal yang lapangannya ingin dipesan.

Hal-hal tersebut akan menghabiskan banyak waktu, ketika lapangan yang ingin dipesan oleh penyewa lapangan futsal ternyata sudah tidak tersedia karena telah dipesan oleh penyewa lainnya, yang kemudian akhirnya harus membuat penyewa tersebut berpindah ke tempat futsal lainnya dengan masalah yang sama yaitu tidak mengetahui secara real time jadwal yang kosong pada setiap lapangan futsal yang disediakan oleh penyedia lapangan futsal tersebut.

Selain itu informasi yang disediakan oleh penyedia lapangan futsal juga pada umumnya masi manual, sehingga informasi yang didapatkan oleh penyewa lapangan futsal tidak akurat. Setelah melakukan penyebaran kuesioner dengan metode validation board untuk mengetahui bahwa permasalahan yang diangkat sesuai dengan permasalahan yang dihadapi dilapangan maka dari masalahmasalah tersebut dapat disimpulkan sangat pentingnya informasi secara real time mengenai jadwal lapangan futsal yang kosong pada setiap penyedia lapangan futsal yang ada dengan membuat marketplace penyedia lapangan futsal untuk membantu penyewa lapangan futsal dalam mendapatkan informasi mengenai setiap penyedia lapangan futsal yang ada dan membantu memberikan informasi jadwal lapangan kosong secara real time dengan tujuan membantu penyewa lapangan futsal dalam mempermudah menentukan penyewaan lapangan futsal dengan memberikan informasi ketersediaan lapangan kosong dan detail penyedia pada setiap lapangan futsal sehingga informasi yang didapatkan oleh penyewa lapangan futsal akan lebih akurat dari jadwal hingga detail tempat lapangan futsal dan detail lapangan yang dimiliki oleh setiap penyedia lapangan futsal yang ingin dipesan oleh setiap penyewa lapangan futsal.

Sistem yang dirancang untuk menjawab permasalah penyewa lapangan futsal adalah sistem marketplace penyewaal lapangan futsal berbasis website dengan bahasa pemograman PHP dengan Framework CodeIgniter serta MySql sebagai databasenya

\subsection{Rumusan Masalah.}

Berdasarkan latar belakang permasalahan diatas, maka rumusan masalah dalam penelitian ini adalah sebagai berikut:

1. Bagaimanakah merancang bangun sistem informasi marketplace penyewaan lapangan futsal berbasis web sebagai media informasi untuk penyewa lapangan futsal ?

2. Apakah implementasi sistem informasi marketplace penyewaan lapangan futsal berbasis web akan membantu penyewa untuk mendapatkan informasi secara real time?

\subsection{Tujuan Penilitian}

Adapun tujuan dari penelitian ini adalah sebagai berikut:

1. Untuk merancang bangun sistem informasi marketplace penyewaan lapangan futsal berbasis web sebagai media informasi untuk penyewa lapangan futsal. 
2. Untuk mengetahui keberhasilan implementasi sistem informasi marketplace penyewaan lapangan futsal berbasis web dalam membantu penyewa untuk mendapatkan informasi secara real time.

\section{Tinjauan Pustaka}

\subsection{Futsal}

Menurut Almahdi (2008) futsal adalah permainan bola yang dimainkan oleh dua tim, yang masing-masing beranggotakan lima orang. Tujuannya adalah memasukkan bola ke gawang lawan, dengan memanipulasi bola dengan kaki. Selain lima pemain utama, setiap regu juga diizinkan memiliki pemain cadangan. Dalam pergantian pemain semua pemain selain penjaga gawang boleh memasuki dan meninggalkan lapangan kapan saja. Pergantian penjaga gawang hanya dapat dilakukan ketika bola tidak sedang dimainkan dan dengan persetujuan wasit. Tidak ada batas pergantian pemain dalam futsal. Jika di sepak bola, pemain yang telah diganti tidak dapat dimainkan kembali pada pertandingan yang sama. Maka, futsal tidak seperti itu. Pemain yang telah terganti pun masih dapat bermain kembali pada pertandingan yang sama. Kata Futsal berasal dari bahasa Spanyol, yaitu Futbol (sepak bola) dan Sala (ruangan), yang jika digabung artinya menjadi sepak bola dalam ruangan.

\subsection{Metode Waterfall}

Waterfall model adalah model yang memacu tim pengembang untuk mengumpulkan dan menentukan apa yang seharusnya dilakukan sebelum sistem dikembangkan (Simarmata, 2010). Model ini terstruktur serta cocok diadaptasi untuk management control.

\subsection{Validation Board}

Dalam idea validation Sidu (2015) menerangkan bahwa eric ries menjelaskan tentang validation board adalah alat yang hebat untuk membantu pengusaha tetap fokus untuk mengambil tindakan saat menerapkan proses Lean Startup. Lean start up adalah pengujian permasalahan tersebut memang dibutuhkan oleh pasar sehingga pengujian dapat dilakukan dan menghindari asumsi pasar yang tidak benar sedini mungkin. Validation board digunakan untuk mencari target constumer yang akan dijadikan objek penelitian, kemudian mencari permasalahan yang dihadapi costumer tersebut dengan membuat asumsi - asumsi yang dirasa adalah sebuah masalah bagi mereka, untuk mengetahui validasi dan invalidasi yang sesungguhnya dan kemudian akan di pivot sehingga menemukan permasalahan costumer yang sesungguhnya.

\subsection{Black Box Testing}

Black box testing adalah pengujian yang dilakukan hanya mengamati hasil eksekusi melalui data uji dan memeriksa fungsional dari perangkat lunak. Jadi dianalogikan seperti kita melihat suatu koatak hitam, namun kita hanya bisa melihat penampilan luarnya saja, tanpa tau ada apa dibalik bungkus hitam nya. Sama seperti pengujian black box, mengevaluasi pengujiannya hanya dari tampilan luarnya (Interfacenya), fungsionalitasnya. tanpa mengetahui apa sesungguhnya yang terjadi dalam proses detilnya (hanya mengetahui input dan output nya saja).

Menurut Nidhra (2012) black box testing juga disebut functional testing sebuah teknik pengujian fungsional yang merancang test case berdasarkan informasi dari spesifikasi.

\section{Metodologi}

\subsection{Metode Penelitian}

Dalam menentukan metode penelitian yang digunakan penulis dalam penelitian ini adalah metode waterfall yang mengarah pada hasil penelitian dengan tujuan yang ingin dicapai, dengan mengolah berbagai data dan informasi 
yang diperoleh dari wawancara pada tempat penyedia lapangan futsal dan penyebaran kuesioner pada penyewa lapangan futsal.

1. Metode Perencanaan

Dalam tahap perencanaan peneliti membuat perencanaan untuk meneliti penyedia lapangan futsal pada metro futsal, bali futsal, victory futal dan penyewa lapangan futsal untuk mendapatkan informasi dan mengetahui permasalahan yang akan diteliti dengan melakukan pengumpulan data dan informasi. Pengumpulan data dan informasi pada perencanaan ini akan dikumpulkan dengan menggunakan metode validation board.

2. Metode Pengumpulan Data

a) Wawancara dan observasi dilakukan di tempat penyedia lapangan futsal, yaitu pada metro futsal, bali futsal dan victory futsal. Wawancara dilakukan terhadap pemilik dan karyawan pengelola untuk mengetahui informasi yang dibuat apakah akan berguna dan dapat membantu mereka dalam memberikan informasi pada penyewa lapangan futsal.

b) Melakukan penyebaran kuesioner dan wawancara dengan metode validation board pada penyewa lapangan futsal, agar mendapatkan informasi, sehingga mengetahui informasi yang dibuat apakah akan berguna untuk penyewa lapangan futsal dalam menentukan penyewaan lapangan futsal.

c) Studi pustaka, melakukan pengumpulan informasi dari buku, teks penelitian terdahulu dan melalui internet sebagai referensi.

3. Metode Analisis dan Desain Sistem

Dalam tahapan analisis, peneliti melakukan beberapa kegiatan diantaranya mempelajari sistem informasi, dan menggambarkan sistem yang sedang berjalan kedalam alat bantu analisis dan perancangan yaitu Flow Chart dari yang sedang berjalan, mencari alternatif pemecahan masalah, dan pemilihan (choice) alternative pemecahan masalah yang tepat. Dalam tahapan desain sistem, peneliti memberikan gambaran tentang perancangan dari sistem yang akan dibuat untuk memberikan alternative pemecahan masalah. Langkah-langkah yang dilakukan peneliti dalam tahapan desain sistem ini ialah membuat tujuan dari perancangan sistem, membuat gambaran umum atau deskripsi global sistem yang dirancang, merancang prosedur sistem yang diusulkan dengan membuat Flow Chart, Use Case Diagram, merancang Basis Data, dan merancang interface atau antar muka program.

4. Metode Perancangan

Menterjemahkan data atau pemecahan masalah ke dalam aplikasi berbasis web yang dirancang dari desain sistem kedalam bahasa pemograman yang telah ditentukan dalam hal ini menggunakan bahasa pemrograman HTML dan PHP dengan Framework CodeIgniter serta MySQL sebagai databasenya. Perangkat lunak pendukung yang digunakan yakni Notepad ++ , Xampp, serta software lain yang mendukung dalam pembuatan program. Setelah dibuat coding maka selanjutnya sistem yang dibangun tersebut diuji menggunakan black box testing untuk mengetahui layak atau tidaknya sistem tersebut untuk diimplementasikan. Apabila tidak layak maka proses coding harus dicek kembali atau perlu tambahan fungsi lainnya.

5. Metode Pengembangan

Dalam tahap pengembangan ini pemecahan masalah yang telah dirancang dan telah dibuat dalam sebuah aplikasi berbasis web, dan telah ditesting untuk ditemukan error 
atau kesalahannya yang kemudian diimplementasikan ketika sudah berhasil berjalan, akan terus dikembangkan untuk mendapatkan hasil yang semakin optimal guna untuk semakin meningkatkan kualitas aplikasi yang telah dibuat sehingga semakin berkembang serta dapat semakin membantu penyewa lapangan futsal dalam menentukan lapangan futsal.

\subsubsection{Instrumen Penelitian}

Adapun instrumen penelitian yang penulis gunakan adalah sebagai berikut:

A. Metode Perencanaan :

a) Melakukan wawancara pada penyedia lapangan futsal untuk mendapatkan informasi dan data.

b) Melakukan wawancara untuk penyewa lapangan futsal guna untuk mendapatkan informasi lebih banyak mengenai kendala apa saja yang

dihadapi guna mengetahui permasalahan lebih dalam serta untuk mengumpulkan data.

B. Metode Pengumpulan Data :

a) Wawancara menggunakan metode validation board.

b) Kuesioner menggunakan metode skala likert.

C. Metode Analisis dan Desain

a) Flowchart : yang menunjukkan proses penyewaan lapangan futsal pada umumnya.

b) Flowchart : yang diusulkan untuk penyewaan lapangan futsal untuk mempermudah dalam menentukan penyewaan lapangan futsal.

c) Use Case Diagram : untuk menggambarkan semua actor yang terlibat didalam sistem.

d) ERD Basis Data : Untuk memberikan basis data yang terstruktur dan efisien dalam pengguunaannya.

D. Metode Perancangan

a) Perangkat Keras
- Prosesor
: Intel Inside

- Memory RAM

: 2 GB RAM

- Harddisk

$: 1 \mathrm{~TB}$

b) Perangkat Lunak

- Sistem Operasi : Windows 8 Pro

- Aplikasi

: Xampp

- Software

: Notepat ++

- Bahasa Pemograman : PHP

- Framework : CodeIgniter

- Basis Data : MySq1

c) Testing : Black Box Testing, untuk mengetahui apakah perangkat lunak berfungsi dengan benar. Selain itu, pengujian Black Box juga merupakan metode perancangan data uji yang didasarkan pada spesifikasi perangkat lunak. Data uji dibangkitkan, dieksekusi pada perangkat lunak dan kemudian keluaran dari perangkat lunak dicek apakah telah sesuai dengan yang diharapkan.

E. Metode Pengembangan

a) Meningkatkan kualitas aplikasi dari segala masukan dan pembaharuan yang ada sehingga aplikasi yang telah dibuat semakin memudahkan penyedia lapangan futsal dalam memberikan informasi guna meningkatkan pelayanan sehingga membantu penyewa lapangan futsal untuk mendapatkan informasi-informasi yang terus meningkat kualitasnya yang mungkin kedepannya akan dikembangkan lebih luas lagi diberbagai lapangan futsal yang ada di Bali bahkan di Indonesia.

b) Terus mengembangkan dan meningkatkan kualitas aplikasi sesuai dengan apa yang dibutuhkan oleh penyewa lapangan futsal sehingga penyewa lapangan futsal menjadi semakin terbantu dalam menentukan penyewaan lapangan futsal dengan aplikasi yang telah dibuat. 


\section{Pembahasan}

\subsection{Hasil Wawancara}

Berdasarkan hasil wawancara yang telah dilakukan terhadap 20 orang perwakilan dari 20 team futsal yang berbeda, dengan menggunakan metode validation board maka didapatkan hasil bahwa memang benar untuk mendapatkan informasi jadwal lapangan yang kosong pada setiap lapangan futsal yang ada dilakukan dengan cara datang langsung dan menanyakan pada penjaga atau penyedia lapangan dan selain itu juga dapat dilakukan dengan cara menghubungi melalui telepon, sehingga para penyewa lapangan futsal tidak mendapatkan informasi secara real time. 17 responden membenarkan bahwa sangat penting untuk mendapat informasi secara real time agar dapat mengetahui jam-jam yang kosong pada setiap tempat dan lapangan futsal yang ada, sehingga memudahkan mereka dalam melakukan penyewaan lapangan futsal, untuk 3 responden lainnya ada yang menyatakan tidak keberatan jika menanyakan atau memesan lapangan melalui telepon, hanya saja pendapat mereka juga sama bahwa informasi mengenai jadwal lapangan yang kosong itu sangat penting, selain itu juga didapatkan hasil bahwa informasi yang diperoleh oleh setiap user dapat terbilang tidak akurat, karena jika lapangan penuh, mereka tidak mengetahui sebelum menanyakannya. Sehingga hal-hal tersebut juga yang biasanya menjadi permasalahan dan pada akhirnya tidak jadi memesan lapangan dikarenakan tidak menemukan waktu yang sesuai dengan pesanan yang diinginkan oleh penyewa. Dari kesimpulan wawancara maka didapakan hasil bahwa para responden membutuhkan sebuah aplikasi yang dapat membantu mereka untuk memberikan informasi secara real time dan secara akurat pada setiap tempat-tempat lapangan futsal yang ada sehingga dapat memudahkan mereka dalam menentukan jam bermain serta dapat memudahkan mereka dalam melakukan pemesanan lapangan futsal pada tempat-tempat yang mereka inginkan.

\subsection{Implementasi}

Pada bagian ini penulis akan menampilkan hasil implementasi dari system yang dibangung yaitu Rancang Bangun Sistem Informasi MarketPlace Penyewaan Lapangan Futsal Berbasis Web Dalam Menentukan Penyewaan Lapangan Futsal. Berikut adalah hasil dari implementasi interface:

\subsubsection{Halaman Register Member}

Halaman register member berisikan Username, Fullname, Telp, Password dan Alamat. Yang digunakan untuk mendaftar sebagai penyewa lapangan futsal.

\subsubsection{Halaman Register Penyedia}

Halaman register member berisikan

Username, Fullname, Telp, No. Rekening, Password dan Alamat. Yang digunakan untuk mendaftar sebagai penyewa lapangan futsal.

\subsubsection{Halaman Login Penyewa dan Penyedi}

Halaman login berisikan Username dan Passoword yang di gunakan untuk akses masuk penyewa dan penyedia lapangan futsal.

\subsubsection{Tampilan Menu Masuk Setelah Login}

Tampilan menu utama setelah berhasil login sebagai user penyewa ataupun sebagai user penyedia. Yang mana tampilan awalnya adalah menampilkan pilihan tempat-tempat futsal yang ada sebagai pilihan untuk penyedia dalam menentukan penyewaan lapangan futsal.

\subsubsection{Proses Pengecekan Jadwal Kosong}

Dalam login penyewa, penyewa dapat melakukan pengcekan pada setiap tempat futsal yang tersedia untuk mendapatkan jadwal sewa lapangan yang ingin dipilih dan dipesan.

\subsubsection{Proses Pemilihan Jadwal Lapangan}

Dalam login penyewa, setelah penyewa melakukan pemilihan jadwal untuk mengetahui ketersediaan jadwal yang kosong pada setiap lapangan futsal yang ada, akan tampil menu sebagai berikut yang kemudian dapat dipilih dan dipesan sesuai dengan jadwal yang dicari dan ingin dipesan. 


\subsubsection{Data Booking Pada Penyewa}

Data yang telah dipilih dan telah dibooking akan masuk kedalam data booking penyewa dan penyedia, berikut adalah tampilan dari data booking yang sudah dipesan oleh penyewa.

\subsubsection{Data Cari Lawan Tanding Penyewa \\ Cari lawan tanding dalam user penyewa}

digunakan untuk mencari teman bermain, dari data booking yang telah di-input dan dipilih oleh penyewa akan masuk kedalam tampilan daftar lawan, sehingga dapat diundang untuk ajakan sparring.

\subsubsection{Info Nonton Bareng dan Turnamen}

Info nonton bareng dan info turnamen digunakan untuk memberikan informasi kepada penyewa lapangan futsal tentang akan adanya nonton bareng ataupun turnamen di tempat futsal yang akan mengadakannya.

\subsubsection{Profil Penyewa Lapangan}

Dalam profil penyewa lapangan, penyewa lapangan dapat melakukan update data jika ingin merubah data seperti foto profil, full name, no telepon dan alamat.

\subsubsection{Data Lapangan Penyedia}

Dalam data lapangan penyedia berisikan jumlah lapangan yang setiap penyedia miliki beserta nama-nama dari setiap lapangan yang dimiliki oleh setiap penyedia dan juga kualitas rumput pada setiap lapangannya.

\subsubsection{Data Tarif Penyedia}

Pada data tarif penyedia berisikan hargaharga dari setiap lapangan yang dimiliki oleh penyedia, beserta waktu bermain baik itu pagisiang, siang-sore atau sore-malam dan biasanya memiliki harga tarif yang berbeda pada setiap tempat dan setiap waktu yang disediakan.

\subsubsection{Data Pemesanan Lapangan}

Dalam data pemesanan lapangan penyedia berisikan data lapangan yang telah dipesan oleh penyewa lapangan.

\subsubsection{Data Info}

Dalam data info penyedia lapangan futsal berisikan segala informasi yang ingin di-input oleh penyedia lapangan futsal, informasi berupa info akan adanya turnamen atau info akan adanya nonton bareng.

\subsubsection{Data Fasilitas Lapangan}

Dalam data fasilitas lapangan penyedia berisikan inputan dari fasilitas apa saja yang dimiliki oleh setiap penyedia lapangan futsal.

\subsubsection{Profil Penyedia Lapangan}

Dalam profil penyedia lapangan penyedia lapangan dapat melakun update data seperti foto profil, fullname, telepon, no. rek dan alamat.

\subsubsection{Admin Mengelola Penyedia}

Dalam admin manajemen penyedia, admin dapat mengontrol kinerja penyedia lapangan futsal, dan dapat melakukan edit maupun mengnonaktifkan penyedia lapangan futsal.

\subsubsection{Admin Mengelola Penyewa}

Dalam admin manajemen penyewa, admin dapat mengontrol kinerja penyewa lapangan futsal, dan dapat melakukan edit maupun mengnonaktifkan penyewa lapangan futsal.

\subsubsection{Setting Situs Admin}

Dalam setting situs admin, admin dapat melakukan setting atau update data pada profil situs admin, data-data tersebut seperti header, kontak phone, email, alamat dan deskripsi yang nantinya akan tampil pada situs admin.

\subsection{Pengujian Sistem}

Berikut ini merupakan hasil dari pengujian sistem marketplace penyewaan lapangan futsal dengan menggunakan metode blackbox testing, untuk mengetahui fungi dari setiap perangkat lunak yang ada sudah berjalan sesuai dengan apa yang diharapakan, dapat dilihat pada tabel 4.1, 4.2 dan 4.3: 
Tabel 4.1 Pengujian Member

\begin{tabular}{|c|l|l|l|}
\hline No & $\begin{array}{l}\text { Menu } \\
\text { yang diuji }\end{array}$ & Fungsi yang diuji & Hasil \\
\hline 1 & Register & - Daftar Sistem & Sesuai \\
\hline 2 & Login & - Login Sistem & Sesuai \\
\hline 3 & $\begin{array}{l}\text { View } \\
\text { Detail }\end{array}$ & $\begin{array}{l}\text { - Menampilkan } \\
\text { Detail Penyedia }\end{array}$ & Sesuai \\
\hline 4 & $\begin{array}{l}\text { Search } \\
\text { Jadwal }\end{array}$ & $\begin{array}{l}\text { - Menampilkan } \\
\text { Jadwal }\end{array}$ & Sesuai \\
\hline 5 & Booking & - Proses Memesan & Sesuai \\
\hline 6 & $\begin{array}{l}\text { Data } \\
\text { Booking }\end{array}$ & $\begin{array}{l}\text { - Menampilkan Data } \\
\text { Pesanan }\end{array}$ & Sesuai \\
\hline 7 & $\begin{array}{l}\text { Data Cari } \\
\text { Lawan }\end{array}$ & $\begin{array}{l}- \text { Menampilkan } \\
\text { Lawan Tanding }\end{array}$ & Sesuai \\
\hline 8 & $\begin{array}{l}\text { Data Info } \\
\text { - Menampilkan Info } \\
\text { Turnamen dan } \\
\text { Nonbar }\end{array}$ & sesuai \\
\hline 9 & $\begin{array}{l}\text { Profil } \\
\text { Penyewa }\end{array}$ & $\begin{array}{l}\text { - Menampilkan Data } \\
\text { Penyewa }\end{array}$ & sesuai \\
\hline
\end{tabular}

Tabel 4.2 Pengujian Penyedia

\begin{tabular}{|c|l|l|l|}
\hline No & $\begin{array}{l}\text { Menu yang } \\
\text { Diuji }\end{array}$ & $\begin{array}{l}\text { Fungsi yang } \\
\text { Diuji }\end{array}$ & Hasil \\
\hline 1 & Register & - Daftar Sistem & Sesuai \\
\hline 2 & Login & - Login Sistem & Sesuai \\
\hline 3 & $\begin{array}{l}\text { Data } \\
\text { Lapangan }\end{array}$ & $\begin{array}{l}\text { - Input Data } \\
\text { Kualitas } \\
\text { Lapangan }\end{array}$ & Sesuai \\
\hline 4 & Data Tarif & $\begin{array}{l}\text { - Input Data } \\
\text { Harga }\end{array}$ & Sesuai \\
\hline 5 & $\begin{array}{l}\text { Data } \\
\text { Pemesanan }\end{array}$ & $\begin{array}{l}\text { - Menampilkan } \\
\text { Data Pesanan }\end{array}$ & Sesuai \\
\hline 6 & Data Info & $\begin{array}{l}\text { - Input Info } \\
\text { Sesuai }\end{array}$ \\
\hline 7 & $\begin{array}{l}\text { Data } \\
\text { Fasilitas }\end{array}$ & $\begin{array}{l}\text { - Input Data } \\
\text { Fasilitas }\end{array}$ & Sesuai \\
\hline 8 & $\begin{array}{l}\text { Profil } \\
\text { Penyedia }\end{array}$ & $\begin{array}{l}\text { - Menampilkan } \\
\text { Data Penyedia }\end{array}$ & Sesuai \\
\hline
\end{tabular}

Tabel 4.3 Pengujian Admin

\begin{tabular}{|r|l|l|l|}
\hline No & $\begin{array}{l}\text { Menu yang } \\
\text { Diuji }\end{array}$ & Fungsi yang Diuji & Hasil \\
\hline 1 & Login & - Login Sistem & Sesuai \\
\hline 2 & $\begin{array}{l}\text { Manajemen } \\
\text { Penyewa }\end{array}$ & $\begin{array}{l}\text { - Mengelola } \\
\text { Penyewa }\end{array}$ & Sesuai \\
\hline 3 & $\begin{array}{l}\text { Manajemen } \\
\text { Penyedia }\end{array}$ & $\begin{array}{l}\text { - Mengelola } \\
\text { Penyedia }\end{array}$ & Sesuai \\
\hline
\end{tabular}

\subsubsection{Hasil Pengujian}

Pada hasil pengujian sistem, sistem yang telah dibuat berjalan sesuai dengan apa yang diharapkan pada tabel pengujian sistem.

\subsection{Pembahasan Kuesioner}

Setelah melakukan pengujian pada sistem aplikasi dengan menggunakan metode blackbox testing dan telah didapatkan hasil sesuai dengan apa yang diharapkan maka peneliti melakukan penyebaran kuesioner pada 20 responden dari 20 team futsal, sehingga mendapatkan hasil bahwa aplikasi yang dibuat tersebut juga sesuai dengan apa yang diharapkan oleh penyewa lapangan, sehingga akan memudahkan penyewa lapangan dalam mendapatkan informasi secara real time dalam melakukan penyewaan lapangan futsal.

\subsubsection{Penentuan Skor Jawaban}

Skor jawaban merupakan nilai jawaban yang akan diberikan oleh responden. Menurut Sugiono (2012), yang dijelaskan pada bukunya bahwa hal pertama yang harus kita lakukan adalah menentukan skor dari setiap jawaban yang akan diberikan.

Tabel 4.4 Penentuan Skor Jawaban

\begin{tabular}{|c|c|}
\hline Skala Jawaban & Nilai \\
\hline Sangat Setuju & 5 \\
\hline Setuju & 4 \\
\hline Kurang Setuju & 3 \\
\hline Tidak Setuju & 2 \\
\hline Sangat Tidak Setuju & 1 \\
\hline
\end{tabular}

\subsubsection{Skor Ideal}

Skor ideal merupakan nilai yang digunakan untuk menghitung skor untuk menentukan rating scale. (Sugiono, 2012), Untuk menghitung jumlah skor ideal (kriterium) dari seluruh item digunakan rumus sebagai berikut :

\section{Skor Kriterium $=$ Nilai Skala $x$ jumlah responden}

Penentuan skor tertinggi adalah 5 dan jumlah responden adalah 20, maka dapat dirumuskan sebagai berikut :

Tabel 4.5 Penentuan Skor Ideal.

\begin{tabular}{|l|l|}
\hline \multicolumn{1}{|c|}{ Rumus } & \multicolumn{1}{c|}{ Skala } \\
\hline $5 \times 20=100$ & Sangat Tidak Setuju / STS \\
\hline $4 \times 20=80$ & Tidak Setuju / TS \\
\hline $3 \times 20=60$ & Kurang Setuju / KS \\
\hline $2 \times 20=40$ & Setuju / S \\
\hline $1 \times 20=20$ & Sangat Setuju / SS \\
\hline
\end{tabular}




\subsubsection{Rating Scale}

Skor yang telah diperoleh kemudian dimasukan kedalam rating scale. Teknik analisis Skala Likert, yaitu 1 s/d 5. Skor maksimum adalah 5 dan minimum adalah 1 $(20 \%$ dari skor maksimum). Kriteria interpretasi skor yang digunakan dalam mengelola hasil kuesioner adalah sebagai berikut :

$$
\begin{array}{ll}
0 \%-20 \% & : \text { Sangat Tidak Setuju } \\
20 \%-40 \% & : \text { Tidak Setuju } \\
40 \%-60 \% & : \text { Kurang Setuju } \\
60 \%-80 \% & : \text { Setuju } \\
80 \%-100 \% & : \text { Sangat Setuju }
\end{array}
$$

\subsubsection{Persentase Persetujuan}

Untuk mengetahui jumlah jawaban dari para responden melalui persentase persetujuan ini dapat digunakan rumus sebagai berikut :

: Prosentase

F : Frekuensi dari setiap jawaban angket

$\mathrm{n}$ : Jumlah skor ideal

100 : Bilangan tetap

Gambar 4.1 Rumus Persentase Persetujuan.

\subsubsection{Hasil Kuesioner}

Berikut ini merupakan skor dari masingmasing item pernyataan yang sudah disebar ke 20 responden.

Kesimpulan keseluruhan kuesioner dapat dihitung dari rata-rata setiap persentase yang telah didapat dengan menggunakan rumus yang dikutip dari Mukhaiyar (2011), yaitu:

$\frac{83+83+84+89+79+86+80+86+81+88}{10}=83,9$

Dari hasil rata-rata persentase tersebut maka dapat disimpulkan bahwa hasil pengamatan skornya adalah $83,9 \%$ Dengan kategori Sangat Setuju / SS.

\section{PENUTUP}

\subsection{Kesimpulan}

Adapun kesimpulan yang didapatkan dalam pembuatan skripsi ini adalah sebagai berikut :

1. Setelah melakukan pembuatan aplikasi berbasis website dengan menggunakan bahasa pemograman PHP dan mysql sebagai databasenya dengan bantuan framework CodeIgniter didapatkan hasil bahwa sistem yang telah dirancang telah berjalan sesuai dengan apa yang diharapkan dan mampu memberikan media informasi secara realtime kepada penyewa lapangan futsal .

2. Setelah dilakukan penyebaran kuesioner pada 20 responden dari 20 team yang ada untuk mengetahui hasil dari implementasi program web yang telah dibuat didapatkan hasil bahwa $83,9 \%$ menyatakan sangat setuju dengan adanya apalikasi tersebut untuk memberikan informasi ketersediaan lapangan futsal pada setiap penyedia lapangan futsal yang ada, sehingga dapat memudahkan para penyewa lapangan untuk mendapatkan informasi secara real time tanpa harus datang langsung atau menanyakan kepada penyedia lapangan yang bersangkutan.

\subsection{Saran}

Adapun saran-saran yang dapat disampaikan dalam pembuatan skripsi ini adalah sebagai berikut :

1. Untuk penelitian selanjutnya diharapkan akan adanya pengembangan lagi pada sistem aplikasi tersebut untuk membantu penyewa lapangan futsal dalam 
mencari teman bermain, seperti membuat sebuah tempat untuk para user dapat bergabung sehingga mereka dapat berkumpul dalam website tersebut untuk membuat sebuah team dengan teman-teman yang sudah mereka kenal ataupun orang yang baru mereka kenal, kemudian jika sudah genap 10 orang atau lebih maka team tersebut sudah dapat melakukan pemesanan lapangan dengan temanteman yang sudah mereka kenal maupun baru mereka kenal pada website tersebut.

2. Untuk penelitian selanjutnya diharapkan kedepannya akan adanya pengembangan pada sistem aplikasi tersebut sehingga sistem tersebut terus berkembang dan akan digunakan oleh banyak user, baik itu penyewa lapangan futsal, maupun penyedia lapangan futsal, yang diharapkan akan digunakan oleh semua penyedia lapangan futsal yang ada dibali sehingga akan membantu user untuk semakin mudah dalam mendapatkan informasi mengenai ketersediaan lapangan kosong jika penyedia lapangan futsal yang tersedia pada aplikasi semakin bertambah, sehingga akan memudahkan penyewa lapangan futsal untuk mendapat informasi maupun melakukan pemesanan lapangan futsal pada tempat yang diinginkan.

\section{Daftar Pustaka}

[1] Almahdi, Z. 2008. Bisnis futsal. Yogyakarta : Ayyana Mangunegara

[2] Andi Sunarto. 2009. Seluk Beluk ECommerce. Yogyakarta: Graha Ilmu.

[3] Fathansyah. 2012. Basis Data. Bandung : Informatika.
[4] Indrajani, S.Kom., MM. 2011. Perancangan Basis Data dalam All in 1. Jakarta : Elex Media Komputindo.

[5] Ismail. Perbankan Syariah. 2011. Jakarta : Kencana Prenada Media Group.

[6] Janner, Simarmata. 2010. Rekayasa Perangkat Lunak. Yogyakarta : Penerbit Andi.

[7] Mukhaiyar, Utriweni. 2011. Statistika Dasar.

[8] Mulyanto A. 2009. Sistem Informasi Konsep dan Aplikasi. Yogyakarta: Pustaka Pelajar.

[9] Nidhra, Srinivas dan Dondeti, Jagruthi. 2012. Black Box And White Box Testing Techniques A Literature Review, International Journal of Embedded Systems and Applications (IJESA) Vol.2, No.2, 8-9.

[10] Pudjo Widodo, Prabowo dan Herlawati. 2011. Menggunakan UML (Unified Modelling Language). Bandung : Informatika.

[11] Rudianto, Arief M. 2011. Pemrograman Web Dinamis menggunakan PHP dan MySQL. Yogyakarta: C.V Andi Offset

[12] Saputro, Haris. dan Sugiri. 2008. Pengelolaan Database Mysql dengan PhpMyadmin. Yogyakarta: Graha ilmu.

[13] Sari, Novita Putu. 2016. Rancang Bangun Sistem MVP Mencari Sparring Partner Secara Online Berbasis Web. Bali : Stimik Primakara.

[14] Sidu Prabowo Dilaksono. 2015. Idea Validation. Bali : Bali Start Up Camp.

[15] Sugiyono. 2012. Memahami Penelitian Kualitatif. Bandung : Alfabeta. 